\title{
ALLELOPATHIC POTENTIAL OF AQUEOUS EXTRACT OF LEAF AND ROOT SESAME ON SICKLEPOD AND BRACHIARIA SEEDS
}

\author{
POTENCIAL ALELOPÁTICO DE EXTRATO AQUOSO DE FOLHA E RAIZ DE \\ GERGELIM EM SEMENTES DE FEDEGOSO E BRAQUIÁRIA \&
}

\section{POTENCIAL ALELOPÁTICO DEL EXTRACTO ACUOSO DE HOJA Y RAÍZ DE SÉSAMO EN SEMILLAS DE FEDEGOSO Y BRACHIARIA \&}

Recebido em: 09/09/2021 - Aprovado em: 17/11/2021 - Publicado em: 29/11/2021

doi) http://dx.doi.org/10.18011/bioeng2021v15n4p523-537

Gustavo Ferreira da Silva1 (ferreirasilvagustavo@gmail.com)

Nilbe Carla Mapeli² (ncmapeli@hotmail.com)

Cassiano Cremon² (cassiano.cremon@gmail.com)

Larissa Chamma' (larissa.chamma@hotmail.com)

Bruno Cesar Ottoboni Luperini' (bruno_luperini@yahoo.com.br)

Gabrieli Ferreira da Silva ${ }^{3}$ (ferreirasilvagabrieli@gmail.com)

Fernando Ferrari Putti ${ }^{4}$ (fernando.putti@unesp.br)

\footnotetext{
${ }^{1}$ Universidade Estadual Paulista "Júlio de Mesquita filho". Botucatu, SP, Brasil.

2 Universidade do Estado de Mato Grosso. Cáceres, MT, Brasil.

3 Instituto Federal de Mato Grosso. Cáceres, MT, Brasil.

${ }^{4}$ Universidade Estadual Paulista "Júlio de Mesquita filho". Tupã, SP, Brasil.
}

\section{RESUMO}

Sicklepod is an important weed in Brazil pastures, but control measures are not yet effective. Thus, allelopathy can be an alternative, due to its ecological importance and for being able to provide new structures sources for agrochemicals production. This research aimed to verify the allelopathic potential of sesame (Sesamum indicum L.) on germination and seedling development of sicklepod (Senna occidentalis L.) and brachiaria (Urochloa brizantha). The treatments were root and leaf extract of sesame, and control (distilled water). Germination percentage, speed of germination, hypocotyl and radicle length were evaluated. Speed of germination, germination percentage and radicle length had no interference from the aqueous extracts. However, in brachiaria these traits had lower values than sicklepod. Although no statistical difference was found for hypocotyl length, the leaf extract showed lower growth of this feature. Allelopathy did not affect germination and speed of germination in both species, but interfered in brachiaria seedling development.

Keywords: Alternative control. Senna occidentalis L. Sesamum indicum L. Urochloa brizantha. Weed. 


\section{INTRODUÇÃO}

Brazil has the largest commercial bovine herd in the world, standing out in the production and export of meat (CARVALHO; ZEN, 2017). It is estimated that $96.5 \%$ of slaughtered cattle are raised on pasture and the remaining $3.5 \%$ have at least one of their breeding phases maintained in this system (FONSECA et al., 2010).

Among the pastures and forages used in Brazilian livestock, the genre Urochloa stands out. However, several pastures established with this genre show signs of degradation, denoting this as one of the main obstacles faced by national livestock, considering that the estimate is approximately $80 \%$ of the areas cultivated with pastures, present degradation characteristics (DIAS-FILHO, 2014).

Several factors are related to the degradation of pastures, among than inadequate initial formation, absence of maintenance fertilization and inadequate grazing management, which consequently favor the emergence and establishment of weeds (IKEDA, 2007; MACEDO, 2009; MECHI et al., 2018).

The control of weeds in pastures, in addition to increasing the cost of production, can also intoxicate and injure animals (CLAUDINO et al., 2016). The damage of weeds to pastures occurs through competition for water, light and nutrients, in addition to producing allelopathic compounds, affecting the quality and quantity of the yield of the forage species (VICTORIA FILHO et al., 2014).

The intensity of weed interference in the pasture depends on the characteristic of the cultivated species (spacing, sowing density, soil conditions, climate, management, season and duration of the period of mutual coexistence), as well as the characteristics of the crop (JAKELAITIS et al., 2010; CAVALCANTE et al., 2017; OLIVEIRA; BRIGHENTI, 2018).

The sicklepod (Senna occidentalis) is the most common weed species found in pastures. This species develops very well in tropical climate conditions and it has high reproductive and developmental capacity, in addition to being considered toxic to animals (WALKER; OLIVER, 2008).

The methods used to control the sicklepod have little efficacy, since the fires carried out on pastures stimulate their germination, a method widely used in the Brazilian Midwest, and the use of chemicals is efficient only in the initial development of the plant, being adults more resistant to this control (DIAS-FILHO, 1990; JABRAN et al., 2015; Müller-Stöver et al., 2016). 
Alternative methods are being developed, which are environmentally safe and biodegradable in nature, in order to reduce the use of synthetic herbicides (BAJWA et al., 2016). Alternative control is an option for the replacement of agrochemicals, favoring the reduction of its use and minimizing the damage caused to the environment (CARVALHO et al., 2012).

Allelopathy is the ability of plants, algae and microorganisms to produce chemical substances that, released into the environment, favorably or unfavorably, directly or indirectly, affecting the develop of other species (SILVA et al., 2017).

Allelopathic sesame (Sesamum indicum L.) extracts demonstrated an efficient action in the development of black prick seedlings and reduced the germination percentage of this weed from $80 \%$ to $28 \%$ in relation to the control (PEREIRA, 2007). Although research has shown the effectiveness of using allelopathic substances on weeds (SILVA et al., 2016; ESPINOSA et al., 2019; RIBEIRO et al., 2019), there are few literary references on the use of plant extracts to control sicklepod, requiring further research in this area (SOUZA FILHO et al., 2003).Thus, this study aimed to verify the aqueous extracts allelopathic potential of sesame leaves and roots (Sesamum indicum L.) in germination and development of sicklepod (Senna occidentalis L.) and brachiaria (Urochloa brizantha) seedlings.

\section{MATERIAIS E MÉTODOS}

The experiment were carried out in the Botany Laboratory of the Mato Grosso State University (UNEMAT). Allelopathic potential of aqueous extract of leaves and root sesame (Sesamum indicum L.) in seeds of sicklepod (Senna occidentalis) and brachiaria grass (Brachiaria brizantha) were analized by germination test trials (SGI and germination percentage) and initial seedling development (length of hypocotyl and root length).

For the acquisition of sesame leaves and roots, it was sown in the school garden of the Dr. José Rodrigues Fontes State School, in Cáceres - MT. The seeds were acquired through donation. The collection of leaves and roots being carried out with the aid of scissors, where the plants were retained in full. Soon afterwards the vegetative parts used were taken to the Botanical Laboratory of UNEMAT for the preparation of the extracts.

To obtain the aqueous extracts of sesame leaves and roots, $100 \mathrm{~g}$ of each vegetative part beaten in a blender with $500 \mathrm{~mL}$ of distilled water were used separately. The solutions were obtained strained in cotton and placed in glasses covered with aluminum foil and 
placed in a refrigerator for a minimum period of 10 days with a temperature of approximately $7 \stackrel{\circ}{ } \mathrm{C}$.

The extracts had a single concentration of 1:5 (w/v), being compared with distilled water, which served as a witness.

In this way, two treatments were obtained with aqueous extracts of leaves and roots of sesame, in the concentration 1:5, and the control, used in seeds of sicklepod and brachiaria.

Sicklepod seeds were obtained from field collection, in a rural property in Cáceres (MT), homogenized, packed in paper bags, stored at room temperature until use, and identified according to the literature by LORENZI (2000).

Brachiaria seeds also used for analysis were obtained from local stores (germination $=62 \%$ ). The seeds of sicklepod and brachiaria grass underwent a process of breaking dormancy before the test, using $35 \mathrm{~mL}$ of concentrated sulfuric acid $\left(\mathrm{H}_{2} \mathrm{SO}_{4}\right)$, where the seeds of sicklepod and brachiaria were kept immersed for 20 and 15 minutes, respectively, in acid, washed in running water for 5 minutes and dried in the shade (BRASIL, 2009).

Seed germination was carried out according Brasil (2009), using gerbox with four replications of 20 seeds distributed on two sheets of Germitest paper, moistened with $5 \mathrm{~mL}$ of aqueous extract or water, depending on the treatment. The gerboxes were kept at an average temperature of $28.5^{\circ} \mathrm{C}\left( \pm 2^{\circ} \mathrm{C}\right)$, under constant light in the germination chamber. The seeds were moistened whenever necessary.

Seed germination counts were performed daily for 20 days. The seeds were considered germinated when the protrusion of the radicle through the integument became visible $(2 \mathrm{~mm})$. The speed of germination index (SGI) were calculated using the following formula proposed by MAGUIRE (1962).

$$
S G I=\frac{G 1}{N 1}+\frac{G 2}{N 2}+\frac{G 3}{N 3}+\cdots+\frac{G n}{N n}
$$

Where:

$G$ is number of germinated seedlings, computed in the first, second, third and until the last count;

$\mathrm{N}$ is number of sowing days in the first, second, third and until the last count;

After the end of the germination, the hypocotyl and radicle length $(\mathrm{cm})$ were measured using graph paper. 
The experimental design adopted was completely randomized, with ten replications.

The germination percentage variable was transformed into a sine arc $\frac{\sqrt{x}}{100}$. The variables were analyzed statistically through the normality test (Lilliefors) and homogeneity of variances (Cochran and Bartlett) and when significant, ANOVA was performed. The treatment means were compared using the Tukey test, at $5 \%$ probability.

\section{RESULTADOS E DISCUSSÃO}

The aqueous extracts used did not influence sicklepod and brachiaria germination, as shown in Figure 1. The average values obtained for germination percentage were $16.84 \% ; 17.78 \%$ and $17.85 \%$ for sicklepod and $8.59 \% ; 7.75 \%$ and $9.81 \%$ for brachiaria grass, being root extract, leaf extract and control, respectively.

Figura 1 - Germination percentage of sicklepod (Senna occidentalis) and brachiaria (Brachiaria brizantha) seeds submitted to the aqueous extracts of sesame leaves and roots (Sesamum indicum). It was compared the treatments within the specie. The means followed by the same letter do not differ by Tukey's test at $5 \%$ probability.

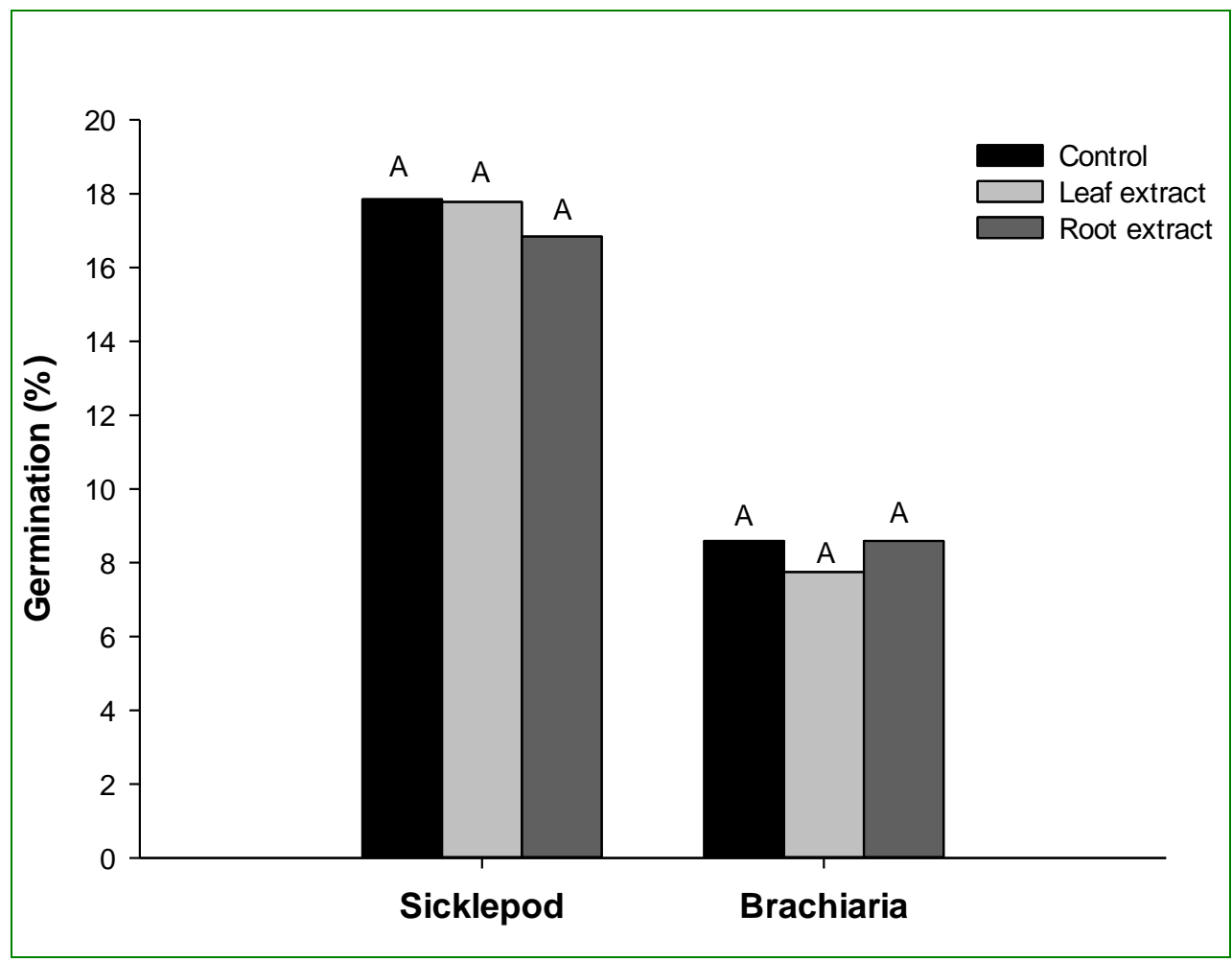

Source: Original results. 
These results demonstrate that the germination percentage of both species was low, brachiaria still having the lowest percentage when compared to the sicklepod. This fact may be due to the type of experimental conduction to which they were subjected, as the test was

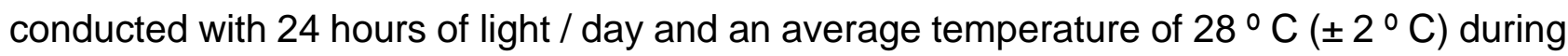
the entire period because of the germination chamber that stored seeds only this configuration. Since it is recommended to use 8 to 12 hours of light / day with temperature at 25 $\mathrm{C}$, for brachiaria seeds (AZANIA et al., 2003; CHIODINI; CRUZ-SILVA, 2013) and constant lighting at $25^{\circ} \mathrm{C}$ for the sicklepod seeds (BORGES et al., 1997), it can be inferred that the light factor may have caused low seed germination for both species.

Thus, it may be that the effects of allelochemicals present in the different extracts were suppressed by the experimental conditions. However, many times, the allelopathic effect may not occur on the germination percentage, but on the SGI or another process parameter (TEIXEIRA; BONFIM, 2014).

The aqueous extracts of leaves and sesame roots did not significantly interfere sicklepod and brachiaria speed of germination. However, brachiaria had a lower speed of germination than sicklepod, (Figure 2). The average of speed of germination index made it possible to evaluate the average germination time, in the sicklepod seeds were $3.77 ; 4.08$ and 4.45 and in brachiaria $0.87 ; 0.65$ and 1.11 for root extract, leaf extract and control, respectively. Similar results were obtained by SOUZA FILHO et al. (2003), using aqueous extracts of Calopogonium mucunoides in various weeds. However, ARAUJO et al. (2018), observed that the aqueous extact affects germination of lettuce seeds. 
Figure 2 - Speed of germination index (SGI) of sicklepod seeds (Senna occidentalis) and brachiaria grass (Brachiaria brizantha) submitted to the aqueous extracts of sesame leaves and roots (Sesamum indicum). It was compared the treatments within the specie. The means followed by the same letter do not differ by

Tukey's test at $5 \%$ probability.

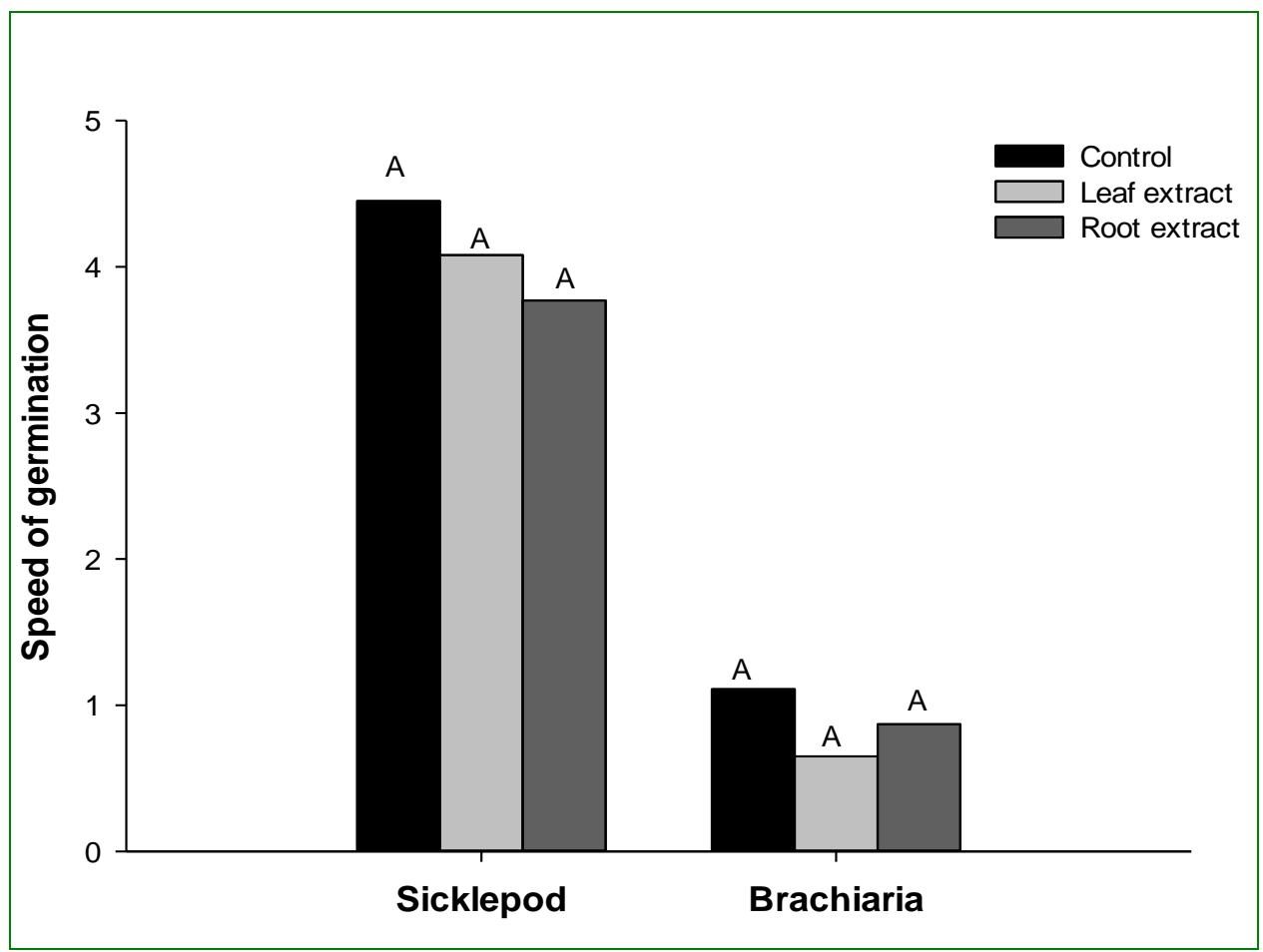

Source: Original results.

The data confirmed that analyzing only the percentage of germination and the SGI does not provide sufficient information regarding the seedling development process, which demonstrates the importance of evaluating the length of the hypocotyl and radicle to better verify the behavior of the species in the germination and development.

However, the length of the hypocotyl was also not influenced by the treatments. However, the sesame leaf extract applied to the brachiaria seedlings provided less growth of the hypocotyl (Figure 3). This may have occurred due to the higher concentrations of allelochemicals (lecithin, sesamine, mircine and tannins) being present in the leaves of plants, when compared to the roots (WANDSCHEER; PASTORINI, 2008; SILVEIRA et al., 2021). 
Figure 3 - Hypocotyl length of sicklepod seedlings (Senna occidentalis) and brachiaria grass (Brachiaria brizantha) submitted to aqueous extracts of sesame leaves and roots (Sesamum indicum). It was compared the treatments within the specie. The means followed by the same letter do not differ by Tukey's test at $5 \%$ probability.

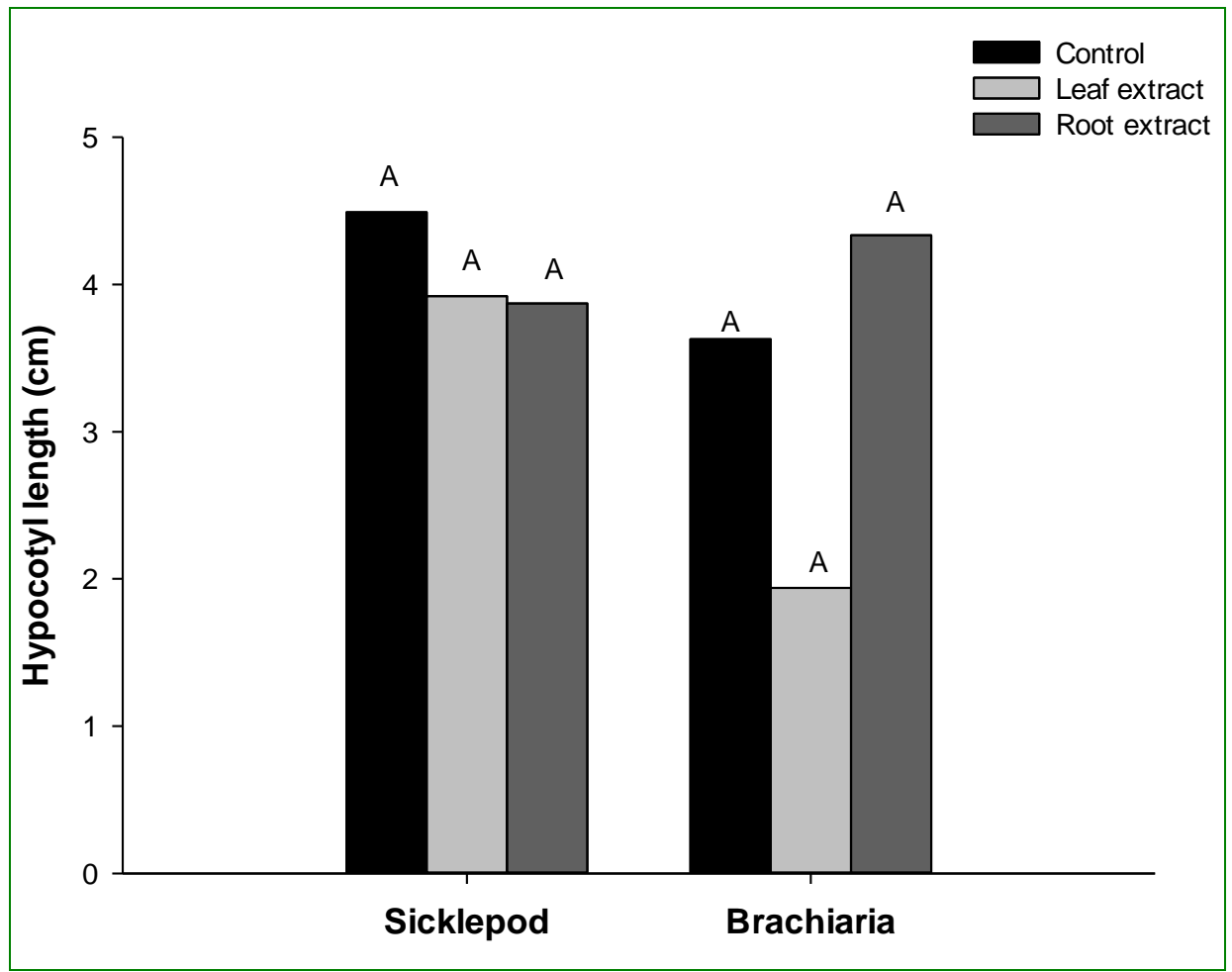

Source: Original results.

The fact that sicklepod seedlings do not suffer interference from both extracts may be linked to the more pronounced specificity of secondary compounds in causing negative allelopathic effect only in brachiaria grass seedlings.

The seedlings of sicklepod did not differ statistically in the length of the radicle with the different treatments to which they were submitted. In the brachiaria seedlings, the sesame leaf extract provided less root growth compared to the control treatment. However, the treatment that used sesame root extract did not differ significantly from the control treatment, as shown in Figure 4. 
Figure 4 - Radicle length of sicklepod seedlings (Senna occidentalis) and brachiaria grass (Brachiaria brizantha) submitted to aqueous extracts of sesame leaves and roots (Sesamum indicum). It was compared the treatments within the specie. The means followed by the same letter do not differ by Tukey's test at $5 \%$ probability.

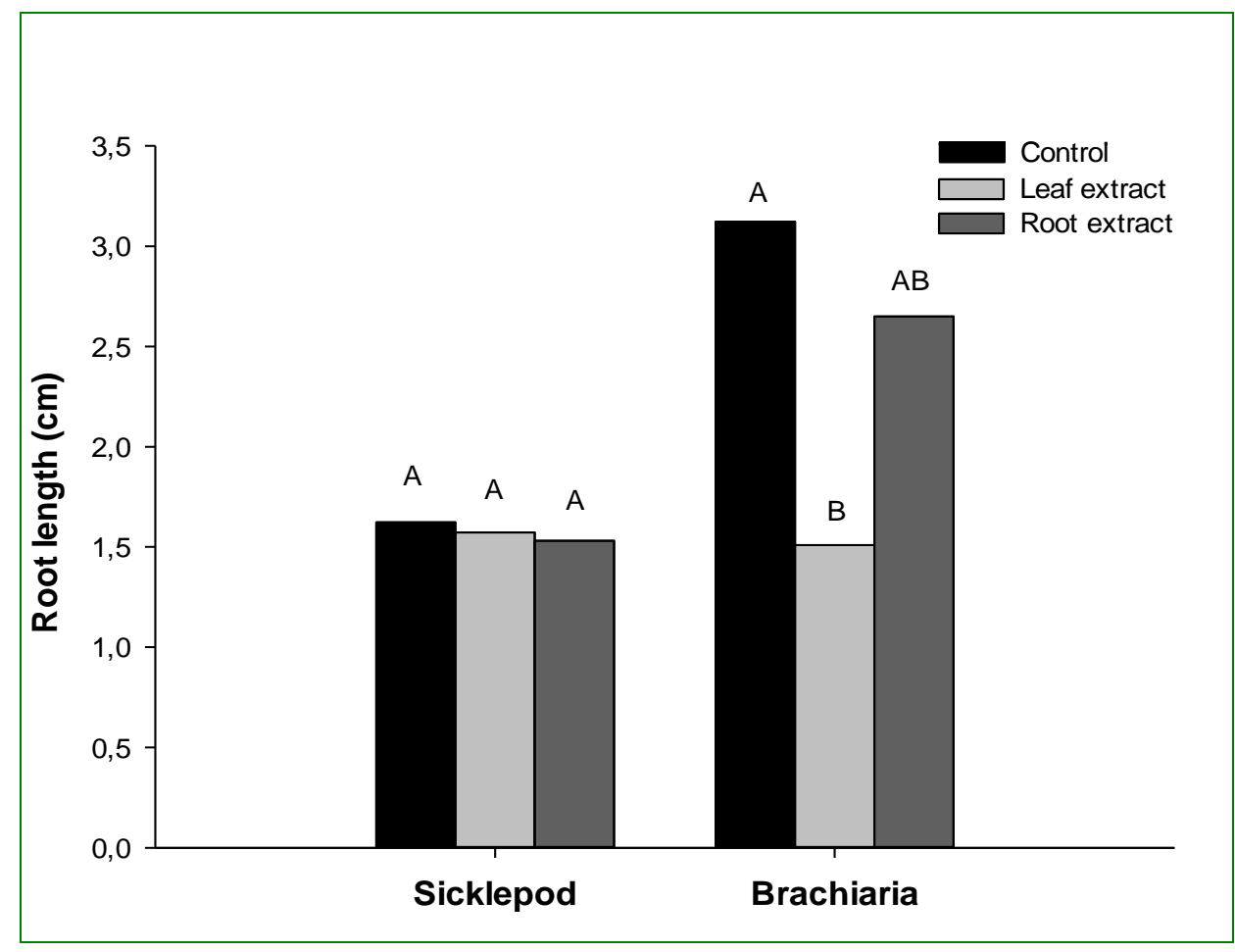

Source: Original results.

The sesame leaf extract showed potential to delay the hypocotyl and radicle lenght seedling development (Figures 3 and 4).

According to SOUZA FILHO (2003), the allelopathy effects on the lengthening of grass root can affect the competitive capacity of these crops by factors essential to survival, such as water and nutrients, with the main consequence of decreased productivity and longevity of pasture, and with negative effects on reducing pasture maintenance costs.

The results obtained suggest that the development of the hypocotyl and radicle are more susceptible to the action of sesame extracts when compared to the germination percentage and the speed of germination. In this way, the data indicate that allelopathic compounds possibly act on the seedling development, having greater expression in brachiaria.

In general, the aqueous leaf and root sesame extract at a concentration of 1:5 (w:v) did not affect the sicklepod initial development, one of the main weeds found in brazilian pastures. However, it negatively affected the brachiaria seedlings development, reducing the length of the hypocotyl and radicle, therefore, it is not recommended to apply this extract 
in this concentration in pasture areas cultivated with $U$. brizantha These results highlight the need for further studies for an alternative management of this weed in pastures (sicklepod), so that it does not harm the agroecosystem. Within this line of allelopathy, it may be that other concentrations of the aqueous leaf and root sesame extract are effective at the control of Senna occidentalis.

It is also worth noting that although brachiaria is the main species cultivated in brazilian pastures (PAULA et al., 2012; BEZERRA et al., 2020), in many agricultural areas, mainly grain production, this species is considered a difficult to control weed (BIANCO; TONHÃO; PITELLI, 2005; FORTE et al., 2018), thus, for these cases, the use of aqueous leaf and root sesame extract is indicated for the control of $U$. brizantha in the initial phase of development.

\section{CONCLUSÕES}

Sesame extracts do not have allelopathic effect on germination percentage and speed of germination index of sicklepod weed (Senna occidentalis) and brachiaria crop (Urochloa brizantha). However, the aqueous extract of sesame leaves negatively affects the radicle and hypocotyl length of brachiaria. Thus, it is application is not recommended in areas of pastures cultivated with U. brizantha.

\section{REFERÊNCIAS}

ARAUJO, E. C. G.; SILVA, T. C.; LIMA, T. V. Efeitos alelopáticos de Sesbania virgata (cav.) Pers na germinação de sementes de alface. Revista Engenharia na Agricultura, v. 26, n. 2, p. 101-109, 2018. https://doi.org/10.13083/reveng.v26i2.862.

AZANIA, A. A. P. M,; MARQUES, M. O.; PAVANI, M. C. M. D.; AZANIA, C. A. M. Germinação de sementes de Sida rhombifolia e Brachiaria decumbens influenciada por vinhaça, flegmaça e óleo de fúsel. Planta daninha, v. 21, n. 3, p. 443-449, 2003. http://dx.doi.org/10.1590/S0100-83582003000300013.

BAJWA, A. A.; CHAUHAN, B. S.; ADKINS, S. W. Morpho-physiological responses of two Australian biotypes of parthenium weed (Parthenium hysterophorus L.) to soil moisture stress. Twentieth Australasian Weeds Conference, 11-15, 2016. 
BEZERRA, J. D. V.; EMERENCIANO NETO, J. V.; ALVES, D. J. S.; BATISTA NETA, I. E.; GALDINO NETO, L. C.; SANTOS, R. S.; DIFANTE, G. S. Características produtivas, morfogênicas e estruturais de cultivares de Brachiaria brizantha cultivadas em dois tipos de solo. Research, Society and Development, 9, v. 7, e129972947, 2020.

http://dx.doi.org/10.33448/rsd-v9i7.2947

BIANCO, S.; TONHÃO, M. A. R.; PITELLI, R. A. Crescimento e nutrição mineral de capimbraquiária. Planta Daninha, v.23, n.3, p. 423-428, 2005. https://doi.org/10.1590/S0100$\underline{83582005000300005}$

BORGES, E. E. L.; BORGES, R. C. G.; PAULA, N. F. Efeito da temperatura e do estresse hídrico na germinação de sementes de fedegoso (Senna macranthera (collad.) Irwin et Barn. e de Leucaena leucocephala (lam.) de Wit. Revista Brasileira de Sementes, v. 19, n. 2, p. 155-158, 1997. http://dx.doi.org/10.17801/0101-3122/rbs.v19n2p155-158.

BRASIL, Ministério da Agricultura e Reforma Agrária. Regras para análise de sementes. Brasília: SNDA/DNDV/CLAV. 2009. 399p.

CARVALHO, T. B.; ZEN, S. A cadeia de Pecuária de Corte no Brasil: evolução e tendências. Revista iPecege, v. 3, n. 1, p. 85-99, 2017.

http://dx.doi.org/10.22167/r.ipecege.2017.1.85.

CARVALHO, W. P.; CARVALHO, G. J.; ANDRADE, M. J. B.; FONSECA, G.; ANDRADE, L.; OLIVEIRA, D. P.; VALACI, F. Alelopatia de adubos verdes sobre feijoeiro comum (Phaseolus vulgaris L.). Revista brasileira de Biociências, v. 10, n.1, p.93-86, 2012.

CAVALCANTE, J. T.; FERREIRA, P. V.; CUNHA, J. L. X. L; SILVA JÚNIOR, A. B.; SILVA, M. T.; CARVALHO, I. D. E. Períodos de interferência de plantas daninhas em genótipos de batata-doce. Cultura Agronômica, v. 26, n. 4, p. 640-656, 2017.

http://dx.doi.org/10.32929/2446-8355.2017v26n4p640-656.

CHIODONI, B. M.; CRUZ-SILVA, C. T. A. Efeito da temperatura na germinação de sementes de Brachiaria brizantha cv. Marandu (Hochst. Ex A. Rich.) Stapf (Poaceae). Revista Varia Scientia Agrárias, v. 3, n. 2, p. 105-113, 2013.

CLAUDINO, A.; MARTIN, L. F.; MANDRO, M. A. Controle de plantas daninhas em pastagens. Universidade de São Paulo - Escola Superior de Agricultura "Luiz de Queiroz", Departamento de Produção Vegetal - LPV. Piracicaba-SP, 2016.

DIAS-FILHO, M. B. Plantas invasoras em pastagens cultivadas da Amazônia: estratégias de manejo e controle. EMBRAPA-CPATU. 1990. 103p.

DIAS-FILHO, M. B. Diagnóstico das pastagens no Brasil. Embrapa Amazônia OrientalDocumentos (INFOTECA-E), 2014.

ESPINOSA, R. Z.; LIBÓRIO, F. H. M.; SILVA, L. I.; ZONETTI, P. C.; MANNIGEL, A. R.; FELIPE, D. F.; GONÇALVES-ZULIANI, A. M. O.; BIDO, G. S. Atividade alelopática de extrato aquoso de Eucalyptus grandis Hill ex Maiden sobre alface (Lactuca sativa L.) e picao-preto (Bidens pilosa L.). Revista Valore, v. 4, p. 1-14, 2019.

https://doi.org/10.22408/reva4020193111-14. 
FONSECA, D. M.; SANTOS, M. E. R.; MARTUSCELLO, J. A. Importância das forrageiras no sistema de produção. In: FONSECA, D. M.; MARTUSCELLO, J. A. (Eds). Plantas forrageiras. Viçosa: UFV, 2010. p.13-29.

FORTE, C. T.; GALON, L.; BEUTLER, A. N.; REICHERT JR., F. W.; MENEGAT, A. D.; PERIN, G. F.; TIRONI, S. P. Cultivation systems, vegetable soil covers and their influence on the phytosocyology of weeds. Planta Daninha, v. 36, e018176776, 2018.

https://doi.org/10.1590/s0100-83582018360100099

IKEDA, F. S.; MITJA, D.; VILELA, L.; CARMONA, R. Banco de sementes no solo em sistemas de cultivo lavoura-pastagem. Pesquisa Agropecuária Brasileira, v. 42, n. 11, p. 1545-1551, 2007. http://dx.doi.org/10.1590/S0100-204X2007001100005.

JABRAN, K.; MAHAJAN, G.; SARDANA, V.; CHAUHAN, B. S. Allelopathy for weed control in agricultural systems. Crop Protection, v. 72, p. 57-65, 2015.

https://doi.org/10.1016/j.cropro.2015.03.004.

JAKELAITIS, A.; GIL. J. D. O.; SIMÕES, L. P.; SOUZA, K. V.; LUDTKE, J. Efeitos da interferência de plantas daninhas na implantação de pastagem de Brachiaria brizantha.

Revista Caatinga, v. 23, n. 1, p. 8-14, 2010.

LORENZI, H. Plantas daninhas do Brasil: terrestres, aquáticas, parasitas, tóxicas e medicinais. 3.ed. Nova Odessa: Instituto Plantarum. 2000. 608 p.

MACEDO, M. C. M. Integração lavoura e pecuária: o estado da arte e inovações tecnológicas. Revista Brasileira de Zootecnia, v. 38, n. 1, p. 133-146, 2009.

https://doi.org/10.1590/S1516-35982009001300015.

MAGUIRE, J. B. Speed of germination-aid in selection and evaluation for seedling emergence vigor. Crop Science, v.2, n.2, p.176-177, 1962. DOI:

https://doi.org/10.2135/cropsci1962.0011183X000200020033x.

MECHI, I. A.; SANTOS, A. L. F.; RIBEIRO, L. M.; CECCONI, G. Infestação de plantas daninhas de difícil controle em função de anos de consórcio milho-braquiária. Revista de Agricultura Neotropical, v. 5, n. 3, p. 49-54, 2018.

https://doi.org/10.32404/rean.v5i3.1642.

MÜLLER-STÖVER, D.; NYBROE, O.; BARAIBAR, B.; LODDO, D. EIZENBERG, H.; FRENCH, K.; SONDERSKOV, M.; NEVE, P.; PELTZER, D. A.; MACZEY, N.;

CHRISTENSEN S. Contribution of the seed microbiome to weed management. Weed

Research, v. 56, n. 5, p. 335-339, 2016. https://doi.org/10.1111/wre.12218.

OLIVEIRA, M. F.; BRIGHENTI, A. M. Controle de plantas daninhas: métodos físico, mecânico, cultural, biológico e alelopatia. Embrapa Milho e Sorgo-Livro técnico (INFOTECA-E). 2018.

PAULA, C. C. L.; EUCLIDES, V. P. B.; LEMPP, B.; BARBOSA, R. A.; MONTAGNER, D. B.; CARLOTO, M. N. Acúmulo de forragem, características morfogênicas e estruturais do capim-marandu sob alturas de pastejo. Ciência Rural, v. 4, n. 1, p. 2059-2065, 2012. https://doi.org/10.1590/S0103-84782012005000084 
PEREIRA, L. M. Potencial alelopático de gergelim (Sesamum indicum L.) na germinação e desenvolvimento de plântulas de picão-preto (Bidens pilosa). 2007. 57p. Monografia (Trabalho de Conclusão de Curso em Agronomia). Universidade do Estado de Mato Grosso, Cáceres, 2007.

RIBEIRO, J. P. O.; ESPÍRITO SANTO, A. D.; MELO, A. M.; SOUSA, A. C. G.; FERREIRA, L. C.; SILVA, A. F.; PARRELLA, N. N. L. D. Efeito alelopático do extrato aquoso das folhas de Callistemon viminalis (Sol. ex Gaertn.) G. Don sobre a germinação de picãopreto (Bidens pilosa L.). Revista Fitos, v. 13, n.4, p. 270-277, 2019.

https://doi.org/10.32712/2446-4775.2019.832.

SILVA, C. B.; OLIVEIRA, M.; DIAS, J. F.; ZANIN, S. M. W.; SANTOS, G. O.; CÂNDIDO, A. C. S.; PERES, M. T. L. P.; SIMIONATTO, E.; MIGUEL, O. G.; MIGUEL, M. D. Atividade alelopática dos lixiviados de Asemeia extraaxillaris (Polygalaceae) sobre o crescimento de Ipomoea cordifolia. Revista Brasileira de Plantas Medicinais, v. 18, n. 1, p. 215-222, 2016. https://doi.org/10.1590/1983-084X/14 093.

SILVA, E. R. D.; OVERBECK, G. E.; SOARES, G. L. Something old, something new in allelopathy review: what grassland ecosystems tell us. Chemoecology, v. 27, p. 217-231, 2017. https://doi.org/10.1007/s00049-017-0249-x.

SILVEIRA, P. F.; COELHO, M. F. B.; MAIA, S. S. S.; CAMILI, E. C.; SPILLER, C.; VARGAS, S. H. Atividade alelopática de extratos de folhas e sementes de Prosopis juliflora na germinação de alface. Revista em Agronegócio e Meio Ambiente, v. 14, n.2, e8249, 2021. http://dx.doi.org/10.17765/2176-9168.2021v14n2e8249.

SOUZA FILHO, A. P. S.; ALVES, S. M.; FIGUEIREDO, F. J. C. Efeitos alelopáticos do calopogônio em função de sua idade e da densidade de sementes da planta receptora.

Planta daninha, v. 21, n. 2, p. 211-218, 2003. https://doi.org/10.1590/S010083582003000200006.

TEIXEIRA, D. A.; BONFIM, F. P. G. Efeito alelopático de melissa, capim-cidreira, lavanda e alecrim na germinação e vigor de sementes de alface. Biotemas, v. 27, n. 4, p. 37-42, 2014. https://doi.org/10.5007/2175-7925.2014v27n4p37.

VICTORIA FILHO, R.; NETO, A. L.; PELISSARI, A.; REIS, F. C.; DALTRO, F. P. Manejo sustentável de plantas daninhas em pastagens. In: MONQUERO, P. A. Manejo de plantas daninhas em culturas agrícolas. 1 ed. São Carlos: RiMa, 2014, p. 179-207.

WALKER, E. R.; OLIVER, L. R. Weed seed production as influenced by glyphosate applications at flowering across a weed complex. Weed technology, v. 22, n. 2, p. 318325, 2008. https://doi.org/10.1614/WT-07-118.1.

WANDSCHEER, A. C. D.; PASTORINI, L. H. Interferência alelopática de Raphanus raphanistrum L. sobre a germinação de Lactuca sativa L. e Solanum lycopersicon L. Ciência Rural, v. 38, n. 4, p. 949-953, 2008. https://doi.org/10.1590/S0103$\underline{84782008000400007 .}$ 


\section{RESUMO}

O fedegoso é uma importante planta daninha das pastagens brasileiras, mas as medidas de controle ainda não são eficazes. Assim, a alelopatia pode ser uma alternativa, devido à sua importância ecológica e por ser capaz de fornecer novas fontes de estruturas para a produção de agroquímicos. Esta pesquisa teve como objetivo verificar o potencial alelopático de gergelim (Sesamum indicum L.) na germinação e no desenvolvimento de plântulas de fedegoso (Senna occidentalis L.) e braquiária (Urochloa brizantha). Os tratamentos foram extrato de folha e raiz de gergelim e testemunha (água destilada). Foram avaliados a porcentagem de germinação, velocidade de germinação, comprimento do hipocótilo e da radícula. Os extratos aquosos não interferiram na velocidade de germinação, porcentagem de germinação e comprimento da radícula. No entanto, na braquiária essas características apresentaram valores menores do que no fedegoso. Embora nenhuma diferença estatística tenha sido encontrada no comprimento do hipocótilo, o extrato da folha apresentou menor crescimento desta característica. Alelopatia não afetou a germinação e velocidade de germinação em ambas as espécies, mas interferiu no desenvolvimento da plântula de braquiária.

Palavras-chave: Controle alternativo. Senna occidentalis L. Sesamum indicum L. Urochloa brizantha. Planta daninha.

\section{RESUMEN}

Fedegoso es una maleza importante en los pastos brasileños, pero las medidas de control aún no son efectivas. Así, la alelopatía puede ser una alternativa, debido su importancia ecológica y por poder aportar nuevas fuentes de estructuras para la producción de agroquímicos. Esta investigación tuvo como objetivo verificar el potencial alelopático del sésamo (Sesamum indicum L.) en la germinación y desarrollo de plántulas de fedegoso (Senna occidentalis L.) y brachiaria (Urochloa brizantha). Los tratamientos fueron extracto de hoja y raíz de sésamo y control (agua destilada). Se evaluó el porcentaje de germinación, la velocidad de germinación, y la longitude del hipocótilo y la radícula. Los extractos acuosos no interfirieron con la velocidad de germinación, el porcentaje de germinación y la longitud de la radícula. Sin embargo, en brachiaria, estas características mostraron valores más bajos que en el fedego. Aunque no se encontraron diferencias estadísticas en la longitud del hipocótilo, el extracto de hoja mostró un menor crecimiento de esta característica. La alelopatía no afectó la germinación ni la velocidad de germinación en ambas especies, pero interfirió con el desarrollo de plántulas de brachiaria

Palabras-clave: Control alternativo. Senna occidentalis L. Sesamum indicum L. Urochloa brizantha. Maleza. 


\section{LICENÇA DE USO}

Este é um artigo publicado em acesso aberto (Open Access) sob a licença Creative Commons Atribuição 4.0 Internacional (CC BY 4.0), que permite uso, distribuição e reprodução em qualquer meio, desde que o trabalho original seja corretamente citado. Mais informações em: http://creativecommons.org/licenses/by/4.0

\section{CONFLITO DE INTERESSES}

Os autores declaram que não há conflito de interesses neste trabalho.

\section{CONTRIBUIÇÕES AUTORAIS}

Autor 1: Conduziu o experimento, analisou os dados e redigiu o artigo.

Autor 2: Idealizou e orientou a pesquisa, contribuiu com a discussão e revisão do texto.

Autor 3: Coorientou a pesquisa, contribuiu com a discussão e revisão do texto.

Autor 4: Analisou os dados e redigiu o artigo.

Autor 5: Contribuiu com a condução do experimento e análises laboratoriais.

Autor 6: Contribuiu com a condução do experimento e análises laboratoriais.

Autor 7: Contribuiu com a discussão e revisão do texto.

FINANCIAMENTO

O presente trabalho não contou com apoio financeiro.

\section{AGRADECIMENTO}

We would like to thank Mato Grosso State University for the structural support.

\section{COMO REFERENCIAR}

DA SILVA, Gustavo Ferreira et al. Allelopathic potential of aqueous extract of leaf and root sesame on sicklepod and brachiaria seeds. Revista Brasileira de Engenharia de

Biossistemas (Tupã), v. 15, n. 4, p. 523-537, 2021. DOI:

http://dx.doi.org/10.18011/bioeng2021v15n4p523-537.

\section{RESPONSABILIBADE EDITORIAL}

Prof. Dr. Fernando Ferrari Putti ${ }^{1}$, Prof. Dr. Paulo Sérgio Barbosa dos Santos ${ }^{1}$, Prof. Dr. Eduardo Festozo Vicente ${ }^{1}$ e Prof. Dr. Diogo de Lucca Sartori ${ }^{1}$

1 Universidade Estadual Paulista "Júlio de Mesquita Filho", FCE - Faculdade de Ciências e Engenharia, Tupã, SP, Brasil. 